\title{
Vogt-Koyanagi-Harada Disease Associated with Rheumatoid Arthritis
}

\author{
Romatoid Artrit ile İlişkili Vogt-Koyanagi-Harada Hastalığ
}

\author{
Hasan Ali TUFAN,,${ }^{1}$ Ayla AKBAL, ${ }^{2}$ Sedat ARIKAN, ${ }^{1}$ Baran GENCER, ${ }^{1}$ Selçuk KARA, ${ }^{1}$ Abdurrahman TUFAN ${ }^{3}$ \\ ${ }^{1}$ Department of Ophthalmology, Medical Faculty of Çanakkale Onsekiz Mart University, Çanakkale, Turkey \\ ${ }^{2}$ Department of Physical Medicine and Rehabilitation, Medical Faculty of Çanakkale Onsekiz Mart University, Çanakkale, Turkey \\ ${ }^{3}$ Department of Internal Medicine, Medical Faculty of Gazi University, Division of Rheumatology, Ankara, Turkey
}

A 31-year-old male patient was admitted to our eye clinic with the complaints of bilateral blurred vision and photophobia. He also suffered from a severe headache, tinnitus, morning stiffness, and arthralgias. His medical history revealed that he had been receiving care for rheumatoid arthritis (RA) for eight years. The best corrected visual acuity was $20 / 50$ in the left eye and 20/40 in the right. His ocular examination revealed bilateral panuveitis with serous retinal detachment. Optical coherence tomography (OCT) confirmed the presence of bilateral subretinal fluid, while fluorescein angiography (FA) demonstrated a "starry sky" appearance and optic disc staining. The patient was diagnosed with Vogt-Koyanagi-Harada (VKH) disease based on the clinical, FA, and OCT findings. In conclusion, both RA and $\mathrm{VKH}$ disease share many similar genetic and environmental factors in their etiopathogenesis. Therefore,further investigations are required to confirm the association between these two autoimmune diseases.

Key words: Rheumatoid arthritis, serous retinal detachment; Vogt-Koyanagi-Harada disease.

Rheumatoid arthritis (RA) is a chronic, systemic inflammatory disorder that primarily involves the joints, but it may also affect many tissues and organs. The eye is involved in about $25 \%$ of RA patients with variable severity and outcomes. The most common ocular sign in RA is keratoconjunctivitis sicca, which occurs in $15-25 \%$ of patients. ${ }^{[1]}$ Other wellknown ocular complications are scleritis, episcleritis, keratitis, peripheral corneal ulceration, and anterior
Otuz bir yaşında erkek hasta, iki taraflı bulanık görme ve fotofobi yakınmaları ile kliniğimize başvurdu. Hastanın aynı zamanda şiddetli baş ağrısı, çınlama ve sabah tutukluğu ve artralji yakınmaları vardı. Hastanın tıbbi öyküsünde sekiz yıldır romatoid artrit (RA) nedeniyle tedavi edildiği öğrenildi. Düzeltilmiş görme keskinliği sol gözde 20/50 ve sağ gözde 20/40 düzeyindeydi. Oküler muayenede iki taraflı panüveit ve seröz retina dekolmanı izlendi. Optik koherens tomografide (OCT) iki taraflı subretinal sıvı varlığı tespit edilirken, floresein anjiyografide (FA) "yıldızlı gökyüzü" görünümü ve optik disk boyanması gözlendi. Klinik, FA ve OCT bulguları ışığında hastaya Vogt-Koyanagi-Harada (VKH) hastalığı tanısı konuldu. Sonuç olarak, RA ve VKH hastalığı, etyopatogenezinde çeşitli benzer genetik ve çevresel faktörleri paylaşmaktadır. Bu nedenle bu iki otoimmün hastalık arasındaki ilişkiyi ortaya koyan ileri araştırmalar gerekmektedir.

Anahtar sözcükler: Romatoid artrit; seröz retina dekolmanı; VogtKoyanagi-Harada hastalığı.

uveitis. ${ }^{[2]}$ Choroiditis, retinal vasculitis, optic neuritis, episcleral nodules, and exudative retinal detachment are other rare ocular complications that have been reported in the literature.

Vogt-Koyanagi-Harada disease (VKH) is a multisystem disease that principally affects pigmented structures in the ocular, auditory, integumentary, and central nervous systems. Although the etiology of $\mathrm{VKH}$ disease has yet to be elucidated, several studies

Received: March 21, 2013 Accepted: May 19, 2013

Correspondence: Hasan Ali Tufan, M.D. Çanakkale Onsekiz Mart Üniversitesi Tıp Fakültesi Göz Hastalıkları Anabilim Dalı, 17020 Çanakkale, Turkey. Tel: +90 286 - 2635950 e-mail: ha_tufan@hotmail.com 
have suggested that it is a cell-mediated autoimmune disorder in which cytotoxic $\mathrm{T}$ cells target melanocytes. Patients are typically 20-50 years old and present with bilateral granulomatous panuveitis. The diagnosis of VKH disease requires the following: ${ }^{[3]}$

1. No history of penetrating ocular trauma or surgery

2. No evidence of other ocular or systemic diseases

3. Bilateral ocular disease (either a or b):

a) Early manifestation as diffuse choroiditis (focal areas of subretinal fluid or bullous serous retinal detachment)

b) Late manifestation as ocular depigmentation (“Sunset glow" fundus or Sugiura's sign) and other ocular signs (nummular chorioretinal depigmented scars, retinal pigment epithelium clumping, or recurrent/chronic anterior uveitis)

4. Neurological/auditory findings [meningismus, tinnitus, cerebrospinal fluid (CSF), or pleocytosis]

\section{Skin findings (alopecia, poliosis, or vitiligo)}

Herein, we present a case of VKH disease associated with RA. Such a relationship might be vital as both diseases are autoimmune in nature and have a strong association with human leukocyte antigen (HLA)DR4 and HLA-DR1.

\section{CASE REPORT}

A 31-year-old Caucasian man came to our eye clinic complaining of bilateral blurred vision and photophobia that had been occurring for two weeks along with a severe headache, tinnitus, morning stiffness, and arthralgias. His first physical examination eight years earlier had revealed arthritis of the bilateral wrists, right elbow, and the second and third metacarpophalengeal joints. At that time, his erythrocyte sedimentation rate (ESR) and C-reactive protein (CRP) level were $83 \mathrm{~mm} / \mathrm{h}$ and $3 \mathrm{mg} / \mathrm{dl}$ respectively, and he had a highly positive rheumatoid factor (RF) level of $83 \mathrm{IU} / \mathrm{ml}$ (normal range: 0-30 IU/ml). In addition, the patient's American College of Rheumatology (ACR)/European League Against Rheumatism (EULAR) score was a 7. These findings led to a diagnosis of RA, and the patient was started on methotrexate (15 mg/week). At a recent presentation, his systemic examination revealed tenderness over both shoulders and elbows along with alopecia, and he denied having any past history of ocular trauma or ocular surgery. Additionally, the patient's visual acuity was 20/50 in the more severely affected left eye and 20/40 in the right eye. A slitlamp examination revealed $3+$ cells in both anterior chambers and $1+$ cells in both anterior vitreous bodies. A secondary cataract without posterior synechia was also observed. Intraocular pressures as measured by applanation tonometry were $12 \mathrm{mmHg}$ in both eyes, and a dilated fundoscopic examination revealed bilateral serous retinal detachment and optic disc edema (Figure 1a). Furthermore, optical coherence tomography (OCT) confirmed the presence of bilateral subretinal fluid (Figure 1b), and fluorescein angiography (FA) demonstrated early pinpoint areas of hyperfluorescence with a "starry sky" appearance and optic disc staining (Figure 2a). Later phases showed leakage and pooling. Choroidal thickening and a serous retinal detachment was also confirmed via $B$-scan ultrasonography (Figure $2 b$ ).

The patient's routine blood tests were within normal limits, except for an elevated ESR $(53 \mathrm{~mm} / \mathrm{h})$, a CRP level of 1.72 (range: 0-0.8), and RF positivity. Furthermore, his serological tests were positive for anti-toxoplasma immunoglobulin (Ig)G, antiRubella IgG, and anti-cytomegalovirus (CMV) IgG.
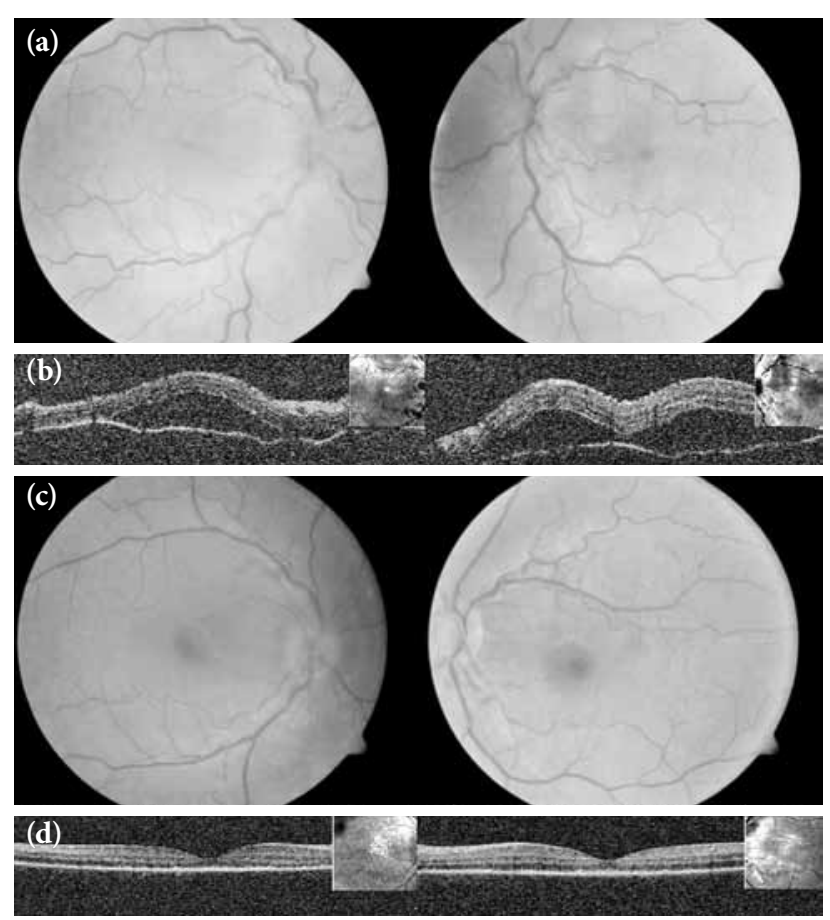

Figure 1. (a) Fundus photography and (b) optical coherence tomography showing bilateral serous retinal detachment and optic disc edema. (c) Fundus photography and (d) optical coherence tomography showing resolution of the subretinal fluid one month after treatment. 
However, the Venereal Disease Research Laboratory (VDRL) and purified protein derivative tests were negative, and a chest X-ray revealed nothing remarkable.

A diagnosis of $\mathrm{VKH}$ was established on the basis of the clinical, FA, and OCT findings. We initiated additional systemic therapy with corticosteroids $(80 \mathrm{mg} /$ day $)$ and also prescribed a topical steroid and cycloplegic drops while continuing the previous immunosuppressive therapy with methotrexate (15 mg/week). During the first week, the patient's ocular disease and neurological and ontological symptoms showed improvement. In addition, the inflammatory signs decreased, and the patient's visual acuity increased to $20 / 20$ in the right eye and 20/25 in the left eye after one month. Furthermore, a followup funduscopic examination revealed resolution of the subretinal fluid and optic disc edema (Figure 1c), and OCT confirmed the resolution of serous retinal detachment in both eyes (Figure 1d).

\section{DISCUSSION}

Vogt-Koyanagi-Harada disease is a granulomatous, inflammatory, multi-system disorder that involves pigmented ocular structures in the eyes, auditory system, meninges, and skin. Diagnosis is based on clinical symptoms and ancillary tests. Our patient had bilateral panuveitis and serous retinal detachment with no history of ocular trauma. This was accompanied by tinnitus and alopecia, thus confirming the diagnosis of complete $\mathrm{VKH}$ disease according to the International Nomenclature Committee's Revised
Diagnostic Criteria. ${ }^{[3]}$ The patient had also a past history of symmetric erosive polyarthritis, including an elevated ESR and RF positivity compatible with RA. To the best of our knowledge, such a relationship between these two diseases has been described only once before in a 40-year-old women who developed RA four years after the diagnosis of $\mathrm{VKH} .{ }^{[4]}$

The exact cause of the VKH disease remains uncertain, but several studies have emphasized the role of $\mathrm{T}$ lymphocytes against the melanocytes in genetically susceptible individuals. Molecular studies also have identified the presence of the Epstein-Barr virus (EBV) genome in the cerebrospinal (CSF) and vitreous fluid of patients with VKH disease. Yamaki et al. ${ }^{[5]}$ demonstrated the cellular immune response of peripheral $\mathrm{T}$ cells or $\mathrm{T}$ cells derived from intraocular fluid against tyrosinase, tyrosinase-related protein 1 (TRP-1) and TRP-2, each of which plays an important role in melanization. In addition, some authors have described a cross-reactive $\mathrm{T}$ cell response between tyrosinase peptides and the CMV antigen in $\mathrm{VKH}$ patients. Interestingly, high titer antibodies to EBV and CMV have also been found in the sera of patients with RA. ${ }^{[6]}$

It has also been suggested that $\mathrm{T}$ helper (Th) cells have a central role in VKH disease development. These cells have at least four distinct subsets: Th1, Th2, Th17, and $\mathrm{T}$ regulatory (Treg). Of these, the Th1 and Th17 cells have been implicated in the development and progression of inflammatory and autoimmune diseases, and an anti-inflammatory role has been attributed to the Th2 and Treg cells.
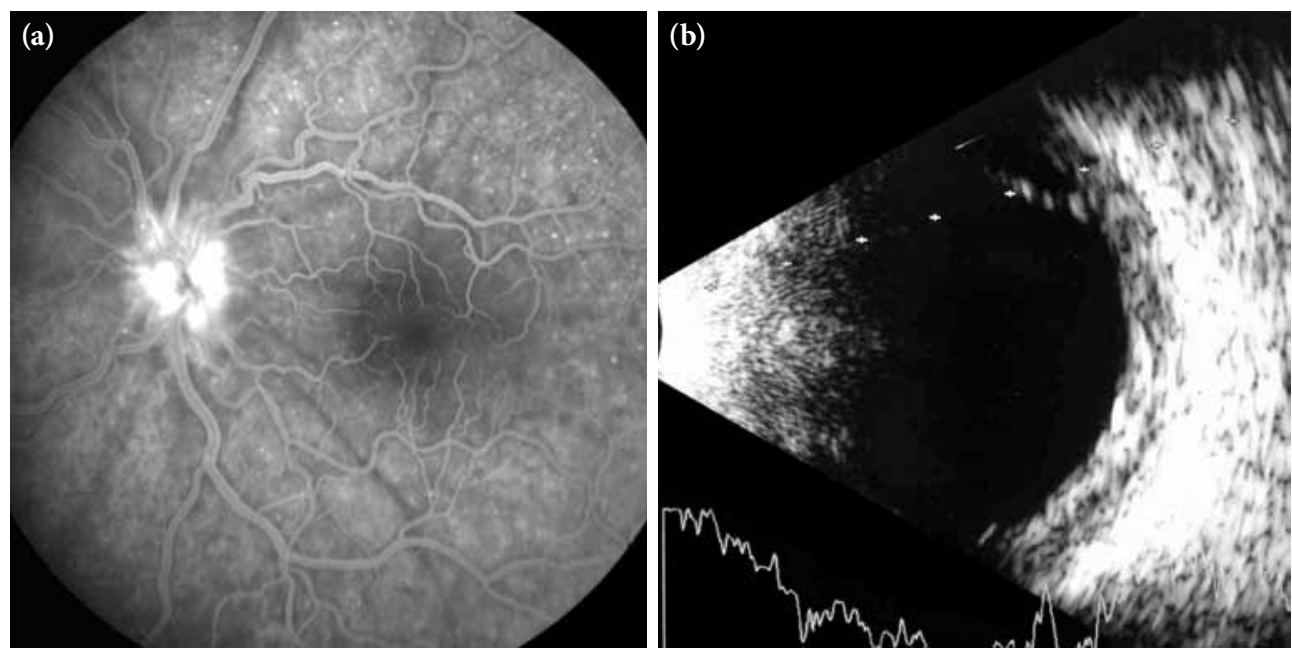

Figure 2. (a) Fluorescein angiography showing bilateral early pinpoint areas of hyperfluorescence with a "starry sky" appearance and optic disc staining. (b) B-scan ultrasonography showing marked choroidal thickening and a serous retinal detachment. 
Moreover, recent studies have indicated that the imbalance of Th1/Th2 and Th17/Treg cells may be responsible for the development and progression of VKH disease. ${ }^{[7]}$ Similarly, it has been demonstrated that the frequency of Th1 and T17 cells is significantly higher in the peripheral blood of RA patients than in healthy controls, whereas Th2 and Treg cells showed some degree of decrease. ${ }^{[8]} \mathrm{T}$ helper cell subsets secrete different cytokines which regulate leukocyte trafficking under physiological and pathological conditions. Furthermore, Th1- and T17-related cytokine dominance has also been demonstrated for both diseases. ${ }^{[7,8]}$

Immunogenetic analysis has indicated a strong association between HLA and VKH, including HLADR4, HLA-DRB1, and HLADRw53. In fact, HLA$\mathrm{DRB1}^{*} 0405$, one of the subtypes of DR4, is the most frequently found genetic allele in VKH patients. Additionally, melanocyte differentiation proteins, which are potential candidates for the autoimmune response that is observed in $\mathrm{VKH}$, are restricted to HLA-DRB1 ${ }^{\star} 0405 .{ }^{[9]}$ A similar association between HLA-DRB1 ${ }^{\star} 0401,{ }^{\star} 0404,{ }^{\star} 0405$, and ${ }^{\star} 01001$ alleles and genetic susceptibility to RA has previously been established. ${ }^{[10]}$

In conclusion, RA is an autoimmune disorder commonly encountered by ophthalmologists, and patients with this disease may present with a variety of ocular manifestations. Early diagnosis of these manifestations is crucial for the timely management of potentially sight-threatening complications. Our case study featured a patient with a very rare case of $\mathrm{VKH}$ disease that was associated with RA, both of which share many similar genetic and environmental factors in their etiopathogenesis. To the best of our knowledge, this is only the second report that has suggested a relationship between $\mathrm{VKH}$ and RA, but further investigations are required to confirm this association.

\section{Declaration of conflicting interests}

The authors declared no conflicts of interest with respect to the authorship and/or publication of this article.

\section{Funding}

The authors received no financial support for the research and/or authorship of this article.

\section{REFERENCES}

1. Matsuo T, Kono R, Matsuo N, Ezawa K, Natsumeda $\mathrm{M}$, Soda $\mathrm{K}$, et al. Incidence of ocular complications in rheumatoid arthritis and the relation of keratoconjunctivitis sicca with its systemic activity. Scand J Rheumatol 1997;26:113-6.

2. McGavin DD, Williamson J, Forrester JV, Foulds WS, Buchanan WW, Dick WC, et al. Episcleritis and scleritis. A study of their clinical manifestations and association with rheumatoid arthritis. Br J Ophthalmol 1976;60:192-226.

3. da Silva FT, Damico FM, Marin ML, Goldberg AC, Hirata $\mathrm{CE}$, Takiuti PH, et al. Revised diagnostic criteria for vogtkoyanagi-harada disease: considerations on the different disease categories. Am J Ophthalmol 2009;147:339-345.e5.

4. Shinzato M, Yamamoto J, Hirata CE, Goldberg AC, Yoshinari NH, Bonfá E. Eye disease in a patient with rheumatoid arthritis. Postgrad Med J 1999;75:676-7.

5. Yamaki K, Gocho K, Hayakawa K, Kondo I, Sakuragi S. Tyrosinase family proteins are antigens specific to VogtKoyanagi-Harada disease. J Immunol 2000;165:7323-9.

6. Musiani M, Zerbini M, Ferri S, Plazzi M, Gentilomi G, La Placa M. Comparison of the immune response to EpsteinBarr virus and cytomegalovirus in sera and synovial fluids of patients with rheumatoid arthritis. Ann Rheum Dis 1987;46:837-42.

7. Chi W, Yang $\mathrm{P}, \mathrm{Li} \mathrm{B}, \mathrm{Wu} \mathrm{C}$, Jin $\mathrm{H}$, Zhu $\mathrm{X}$, et al. IL-23 promotes CD4+ T cells to produce IL-17 in VogtKoyanagi-Harada disease. J Allergy Clin Immunol 2007;119:1218-24.

8. Wang W, Shao S, Jiao Z, Guo M, Xu H, Wang S. The Th17/ Treg imbalance and cytokine environment in peripheral blood of patients with rheumatoid arthritis. Rheumatol Int 2012;32:887-93.

9. Damico FM, Cunha-Neto E, Goldberg AC, Iwai LK, Marin ML, Hammer J, et al. T-cell recognition and cytokine profile induced by melanocyte epitopes in patients with HLA-DRB $1^{\star} 0405$-positive and -negative Vogt-KoyanagiHarada uveitis. Invest Ophthalmol Vis Sci 2005;46:2465-71.

10. Gregersen PK, Silver J, Winchester RJ. The shared epitope hypothesis. An approach to understanding the molecular genetics of susceptibility to rheumatoid arthritis. Arthritis Rheum 1987;30:1205-13. 